\title{
Embodied transport energy analysis of imported wood pellets
}

\author{
A. Duffy \& M. Conroy \\ School of Civil and Building Services Engineering, \\ Dublin Institute of Technology, Dublin, Ireland.
}

\begin{abstract}
The Irish Government has recently introduced a series of capital grants to boost the uptake of domestic wood-pellet technologies in order to reduce greenhouse gas emissions. These have proved popular and have encouraged a significant number of people to switch from gas- and oil-fired boilers to the cleaner fuel. The demand for wood-pellets has, however, greatly exceeded the national capacity for production. The market for wood pellets elsewhere in Europe is also tight and, consequently, a large proportion of Irish pellets are sourced in Canada. This presents possible problems: the carbon emissions associated with longdistance transport may significantly offset the expected environmental benefits; and the resulting need to purchase carbon credits may impact on the Irish Government's rationale for promoting the technology. This paper describes a process-based embodied energy analysis which indicates that the difference in transport embodied energy and $\mathrm{CO}_{2}$ emissions between imported and domestically produced wood pellets is up to $1,403 \mathrm{MJ} /$ tonne and $108 \mathrm{~kg} /$ tonne respectively. Imported pellets have up to four times more embodied energy than those that are domestically-produced. Although this erodes their environmental credentials, it is still a significant improvement when compared to displaced conventional fuels; for example, it is equivalent to $22 \%$ of natural gas $\mathrm{CO}_{2}$ emissions. An economic analysis of present value indicates that the short-term cost to the Irish exchequer of these increased emissions is small.

Keywords: wood pellets, carbon dioxide, transport, embodied energy, cost, policy.
\end{abstract}




\section{Introduction}

Ireland's energy emissions' performance is poor by international standards: in 2004 , energy consumption per capita was 3,870 kgoe and associated greenhouse gas emissions were $10,589 \mathrm{~kg}$; this compares unfavourably with EU27 figures of $3,689 \mathrm{ktoe}$ and $8,180 \mathrm{~kg}$ respectively [1]. Although the country has committed to reducing greenhouse gases to $13 \%$ above 1990 levels by the period 2008-2012, by 2005 emissions were already $25.4 \%$ higher than the baseline [2] and current projections are that this figure will rise to $37 \%$ over the period. Residential energy consumption accounted for almost one quarter of total national fuel consumption in 2005 of which almost $75 \%$ is used for space heating and hot water [3].

The Irish Government has therefore targeted the residential sector for energy demand and greenhouse gas emission reductions through improvements in the thermal performance of dwellings and by promoting the uptake of renewable technologies. Part L (Conservation of Fuel and Energy) of the Building Regulations published in 2006 improved construction standards to minimise fabric and ventilations losses and maximise passive solar heat gains. The Irish government has also sought to increase the uptake of efficient and renewable technologies in the residential sector through capital grants for geothermal systems, solar thermal collectors, wood pellet stoves and wood pellet boilers.

Data from the market indicates that the scheme has been very successful since its inception at the beginning of 2006, that a large uptake of wood pellet boilers is expected and that the policy has encouraged a switch from gas- and oil-fired boilers to the cleaner technology. The demand for wood-pellets has, however, greatly exceeded the national capacity for their production. The market for wood pellets elsewhere in Europe is also tight and, consequently, suppliers in the market have turned to importing the fuel from North America. In Ireland, a large proportion of wood pellets are sourced in Canada.

The import of wood pellets from North America involves significant transport energy use. Consequently, the carbon emissions associated with long-distance wood pellet transport may significantly compromise the fuel's renewable credentials. Moreover, the resulting need to purchase carbon credits may impact on the Irish Government's rationale for promoting the technology.

The objectives of this paper are to:

- $\quad$ quantify the difference in energy consumption and associated carbon emissions between domestically-produced and imported wood pellets;

- assess the extent to which this difference affects the environmental benefits of the imported biomass;

- determine the future cost to the exchequer of any additional carbon released; and

- comment on the resulting policy implications. 


\section{Methodology and assumptions}

The supply chains for both domestically-produced and imported wood pellets are shown in Figure 1. This assumes that production occurs on the site where the sawdust is produced. It can be seen that the only step which differs between the two is that of 'shipping' which represents the long distance transport of the imported pellets from North America. Therefore the comparative analysis considers the additional energy used in transporting the Canadian pellets from their production facility to a distribution centre in Ireland. This assumes that:

- $\quad$ the manufacturing processes employed in both countries are identical; and

- the final local delivery characteristics from the distribution centres to the end-user are the same.

The methodology can be characterised as a comparative 'process based' embodied energy analysis of the two wood-pellet supply chains and therefore suffers from the associated underestimation limitations of this approach [4].
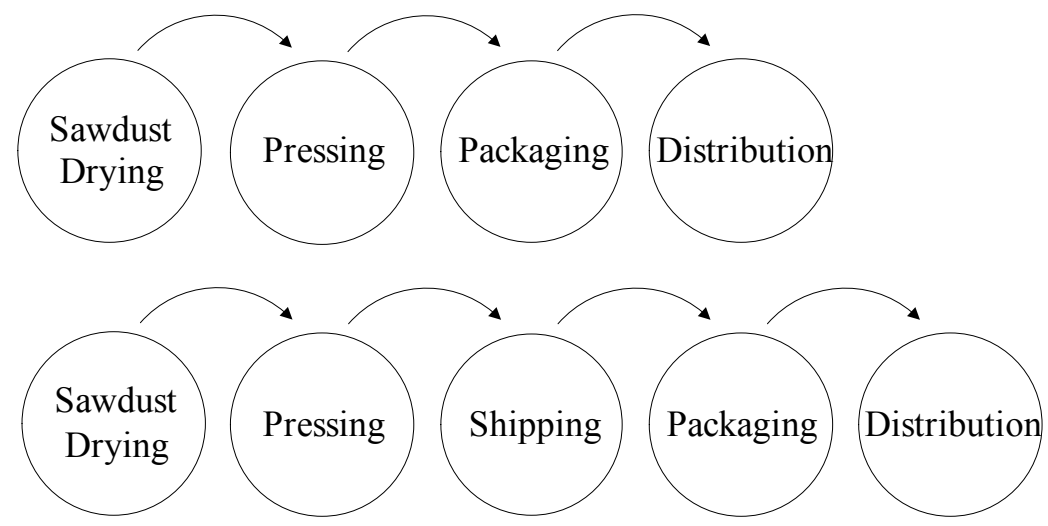

Figure 1: Supply chains for (1) domestically-produced and (2) imported wood pellets.

\subsection{Travel distances}

The long-distance shipping route from Canada to Ireland can be divided into three sections:

- from the manufacturing plant to Canadian port by diesel train or heavy goods vehicle (HGV);

- $\quad$ from Canadian port to Irish port by containerised ship; and

- from Irish port to final distribution centre by HGV.

The locations of Canadian wood pellet manufacturers used as suppliers by Irish distributors were identified and their distances to the nearest Atlantic port established; an average travel distance was then determined. An average distance 
between these and a large Irish port (Cork) was then calculated. Finally, a representative average distance from these ports to a distribution centre in the centre of Ireland was estimated.

\subsection{Fuel consumption and $\mathrm{CO}_{2}$ emissions}

Fuel consumption data are adapted from the BRE [5]. Long-distance HGV transport is based on a truck with a 33 tonne trailer load operating with an average long-distance fuel efficiency of $0.3921 \mathrm{MJ} /$ tonne- $\mathrm{km}$. Local distribution transport is based on a 16 tonne rigid body truck with a fuel efficiency of $0.6544 \mathrm{MJ} /$ tonne-km. The average fuel consumption for a diesel-powered train is taken as $0.1466 \mathrm{MJ} /$ tonne-km and that for shipping is $0.1740 \mathrm{MJ} /$ tonne-km. $\mathrm{A} \mathrm{CO}_{2}$ emission factor for all diesel emissions of $76.7 \mathrm{~g} / \mathrm{MJ}$ has been used.

\subsection{Economic analysis}

Using domestic production as a baseline, economic analysis involves estimating the additional $\mathrm{CO}_{2}$ import emissions, calculating the associated annual cost of carbon credits and determining the discounted present value over a period of 30 years to reflect a long-term policy horizon. A long-term cost of $\mathrm{CO}_{2}$ of $€ 20$ /tonne is used since this is similar to the 2013 forward price listed on Point Carbon in March 2007. A discount rate of $4 \%$ is used to reflect a low interest rate environment.

\section{Results and discussion}

\subsection{Transport}

Table 1 shows the average transport distances, fuel consumptions and carbon dioxide emissions for wood pellets shipped from Canada to Ireland. Figures are given for two options: one where overland transport in Canada is by HGV; and the other by train. It can be seen that the shipping-related fuel consumptions for the $\mathrm{HGV}$ and train options are $1,403 \mathrm{MJ} /$ tonne and $1,025 \mathrm{MJ} /$ tonne respectively. These figures represent $8.3 \%$ and $6.0 \%$ of the total net (total weight) calorific value of the fuel, which is taken to be $17 \mathrm{MJ} / \mathrm{kg}$.

Table 1: Average shipping distances, fuel consumptions and $\mathrm{CO}_{2}$ emissions for each leg of the import journey.

\begin{tabular}{|c|c|c|c|c|c|}
\hline \multirow[t]{2}{*}{ Journey Leg } & \multirow[t]{2}{*}{$\begin{array}{c}\text { Distance } \\
(\mathrm{km})\end{array}$} & \multicolumn{2}{|c|}{$\begin{array}{c}\text { Fuel Consumption } \\
(\mathrm{MJ} / \text { tonne })\end{array}$} & \multicolumn{2}{|c|}{$\begin{array}{c}\text { CO2 Emissions } \\
(\mathrm{kg} / \text { tonne })\end{array}$} \\
\hline & & HGV & Train & HGV & Train \\
\hline Manufacturing plant to nearest & & & & & \\
\hline Canadian port & 1,528 & 599 & 221 & 46 & 17 \\
\hline Canadian port to Irish port by sea & 4,283 & 745 & 745 & 57 & 57 \\
\hline Irish port to distribution centre & 150 & 59 & 59 & 5 & 5 \\
\hline Totals & 5,961 & 1,403 & 1,025 & 108 & 79 \\
\hline
\end{tabular}


Shipping-related $\mathrm{CO}_{2}$ emissions for the $\mathrm{HGV}$ and train options are $108 \mathrm{~kg} /$ tonne and $79 \mathrm{~kg} /$ tonne respectively. When expressed as $\mathrm{CO}_{2}$ emissions per unit calorific value, these figures equate to $23 \mathrm{~g} / \mathrm{kWh}$ and $17 \mathrm{~g} / \mathrm{kWh}$, which is still low when compared to $190 \mathrm{~g} / \mathrm{kWh}$ for natural gas - the fuel used in a condensing gas-fired boiler which represents the best alternative conventional technology.

\subsection{Whole supply chain}

Table 2 shows the energy intensities of all stages in the production and supply chain. A figure of $113 \mathrm{kWh} /$ tonne wood pellets is used for the production (pressing and packaging) of the pellets [6] and a distance of $100 \mathrm{~km}$ has been taken for local distribution. Total energy intensities of $1,875 \mathrm{MJ} /$ tonne and $472 \mathrm{MJ} /$ tonne are calculated for the imported and domestically-produced pellets giving $\mathrm{CO}_{2}$ intensities of $197 \mathrm{~kg} /$ tonne and $90 \mathrm{~kg} /$ tonne respectively. This is equivalent to $\mathrm{CO}_{2}$ emissions of $42 \mathrm{~g} / \mathrm{kWh}$ and $19 \mathrm{~g} / \mathrm{kWh}$ respectively.

Table 2: $\quad$ Energy and carbon intensities per tonne of wood pellet delivered for each step in the supply chain.

\begin{tabular}{lrrrr}
\hline Supply Chain Step & \multicolumn{2}{c}{ Energy Intensity } & \multicolumn{2}{c}{ Carbon Intensity } \\
\hline & \multicolumn{2}{c}{ (MJ/tonne) } & & \multicolumn{2}{c}{ (kg/tonne) } \\
& Imported & Domestic & & Imported Domestic \\
\cline { 2 - 3 } Drying (using biomass waste) & 0 & 0 & 0 & 0 \\
Pressing \& Packaging (MJ/tonne) & 407 & 407 & 85 & 85 \\
Shipping (MJ/tonne) & 1,403 & 0 & 108 & 0 \\
Distribution (MJ/tonne) & 65 & 65 & 5 & 5 \\
Totals & 1,875 & 472 & 197 & 90 \\
\hline
\end{tabular}

\subsection{Economic}

The increased quantities of $\mathrm{CO}_{2}$ emitted due to long-distance transport will affect the projected overshoot of greenhouse gas emissions targets for Canada and Ireland and thus necessitates the purchase of carbon offsets. Under current Kyoto rules the two governments will be required to pay for the additional road transport emissions which occur within their jurisdictions. Although currently exempt from the requirements of Kyoto, the European maritime sector is likely to be included in the future - possibly as early as 2009 [7] - at which stage emissions may be allocated in a number of ways [8], but here it is assumed that the country of destination (Ireland) will pay based on the 'polluter pays' principle.

Table 3 shows the present value to the Irish and Canadian governments of purchasing the necessary carbon credits to offset imported Canadian transport emissions. These figures are based on transporting a quantity of 300,000 tonnes per annum supplying approximately $5 \%$ of the Irish domestic home heating market over 30 years. Based on these assumptions, the Canadian government will be liable for offsetting 13,784 tonnes of $\mathrm{CO}_{2}$ per annum at a total discounted 
cost of $€ 4.2$ million where all pellets are transported using $\mathrm{HGV}$; these figures fall to 5,083 tonnes and $€ 1.6$ million respectively for transport by train. Under current agreements, the Irish government would need to purchase $€ 27,000$ worth of credits per annum with a present value of $€ 400,000$. However, if maritime emissions are included these figure increase to $€ 370,000$ /annum and $€ 5.7$ million respectively.

Table 3: Quantities and present values of $\mathrm{CO}_{2}$ emissions for imported wood pellets under different scenarios.

\begin{tabular}{lccccc}
\hline & \multicolumn{2}{c}{ Canada } & & \multicolumn{2}{c}{ Ireland } \\
\cline { 2 - 3 } \cline { 6 - 7 } & $\mathrm{HGV}$ & train & & $\begin{array}{c}\text { no maritime } \\
\text { emissions }\end{array}$ & $\begin{array}{c}\text { with maritime } \\
\text { emissions }\end{array}$ \\
\hline Additional distance travelled $(\mathrm{km})$ & 1,528 & 1,528 & & 150 & 150 \\
Qualifying sea transport distance $(\mathrm{km})$ & 0 & 0 & & 0 & 4,283 \\
Associated $\mathrm{CO}_{2}$ Emissions $(\mathrm{kg} /$ tonne) & 46 & 17 & & 5 & 62 \\
$\mathrm{CO}_{2}$ Emision for 300,000 tonnes $($ tonnes $)$ & 13,784 & 5,083 & & 1,353 & 18,501 \\
Annual cost of offsets $(€$ '000s) & 276 & 102 & & 27 & 370 \\
Prsent Value $(€$ million) & -4.2 & -1.6 & & -0.4 & -5.7 \\
\hline
\end{tabular}

\section{Conclusions}

There is a significant difference between the environmental impact of wood pellets produced and consumed locally and those which are transported large distances prior to consumption. In this case, the embodied energies of pellets imported from Canada (transported by HGV) and those produced in Ireland are $1,875 \mathrm{MJ} /$ tonne and $472 \mathrm{MJ} /$ tonne respectively; the imported product has four times more embodied energy than the locally-produced one.

However when compared to $\mathrm{CO}_{2}$ emissions from the best alternative natural gas-fired conventional technology, the embodied energy of the imported wood fuel pellets is still relatively low at $42 \mathrm{~g} / \mathrm{kWh}$, equivalent to $22 \%$ that of natural gas. Nonetheless it is significantly higher than its 'carbon neutral' image.

The annual cost to the Irish and Canadian exchequers of supplying 5\% of the Irish domestic market with imported pellets is relatively low at $€ 276,000$ and assuming full maritime allocations - $€ 370,000$ respectively. The present values of these outflows over thirty year are calculated at $€ 4.2$ and $€ 5.7$ million. These costs are small when compared to projected total Irish offset costs of $€ 140$ million/annum.

In summary, the difference in embodied transport energy and $\mathrm{CO}_{2}$ emissions between imported and domestically produced wood pellets is $1,403 \mathrm{MJ} /$ tonne and $108 \mathrm{~kg} /$ tonne respectively assuming overland $\mathrm{HGV}$ transport; these figures fall to $1,025 \mathrm{MJ} /$ tonne and $79 \mathrm{~kg} /$ tonne when overland transport is largely by train. Imported pellets have up to four times more embodied energy than those that are domestically produced. Although this erodes their environmental credentials, it is still a significant improvement on displaced fuels, representing only $22 \%$ of natural gas emissions. The short-term cost to the Irish exchequer of these increased emissions is very small and remains insignificant in the medium term. 


\section{References}

[1] Eurostat, Ireland - Energy Mix Factsheet, 2007, Online. ec.europa.eu/energy/energy_policy/doc/factsheets/mix/mix_ie_en.pdf

[2] Environmental Protection Agency, Ireland's Greenhouse Gas Emissions Provisional Estimate for 2005, 2007, Online. http://www.epa.ie/NewsCentre/ReportsPublications/ClimateChange/GHGE missionsEstimatesBriefingNotes/Greenhouse_Gases_2005.pdf

[3] Howley, M., O’Leary, F. \& Ó Gallachóir, B., Energy in Ireland 1990-2005, Sustainability Energy Ireland, Dublin, pp. 67-73, 2006.

[4] Treloar, G., Extracting embodied energy paths from input-output tables: an input-output-based hybrid energy analysis method. Economic Systems Research, 9(4), 375-391, 1997.

[5] Howard, N, Edwards, S, Anderson, J, BRE methodology for environmental profiles of construction materials, component and buildings. Building Research Establishment, pp.35-39, 2005.

[6] Raymer, A., A comparison of avoided greenhouse gas emissions when using different kinds of wood energy. Biomass \& Bioenergy, 30, pp. 605-617, 2006.

[7] Harvey, F., Brussels targets $\mathrm{CO} 2$ emissions in maritime sector, Financial Times, London, 21 Nov 2005.

[8] Michaelowa, A. and Karsten, K., International maritime transport and climate policy. Intereconomics, 35(3), pp. 127-136, 2000. 